\title{
Exploring cardioprotective potential of esculetin against isoproterenol induced myocardial toxicity in rats: in vivo and in vitro evidence
}

Chitikela P. Pullaiah ${ }^{1,2^{*}}$, Vinod K. Nelson ${ }^{3^{*}}$, Sushma Rayapu ${ }^{4}$, Narasimha Kumar G V ${ }^{5}$ and Thyagaraju Kedam²

\begin{abstract}
Background: Esculetin is a natural coumarin derivative from various plants with multiple pharmacological effects. Hence, the present study was undertaken to explore the cardio protective potential of esculetin against isoproterenol induced myocardial toxicity in rats.

Methods: The treatment schedule was fixed for 28 days and the rats were divided into five groups of six each. Rats of group I received the normal saline and served as normal control, group II was received ISO $(100 \mathrm{mg} / \mathrm{kg}$ body weight) for last two consecutive days of the study and served as disease control. Groups III and IV received esculetin 10 and $20 \mathrm{mg} / \mathrm{kg}$ body weight respectively once a day per oral for 28 days along with ISO for last two consecutive days of the study. Cardiac biomarkers such as CK-MB and LDH, membrane bound Na+ /K+ ATPases activity, myocardial lysosomal enzymes activity and tissue antioxidants status were estimated in the heart tissue samples. The histopathological changes in the myocardium were also assessed. Further, DPPH assay was done to evaluate the free radicals scavenging potential of esculetin. Cytoxicity assay, intracellular ROS levels by DCFDA assay and m-RNA expression of TNF-a, IL-6 and NF-KB by quantitative RT-PCR in H9c2 cell lines.

Results: The increased levels of CK-MB, LDH, LPO, myocardial lysosomal enzymes and membrane bound Na+/K+ ATPase levels by ISO administration was significantly increased with concomitant decrease in tissue antioxidant enzymes such as GSH, Catalase, and SOD. Pre-treatment with esculetin for 28 days has significantly decreased the levels of cardiac bio-markers, lysosomal enzymes, membrane bound $\mathrm{Na}+/ \mathrm{K}+$ ATPase levels as well as Lipid peroxides which is in contrary to the ISO group. Amelioration of the antioxidant levels were also found in esculetin treated groups. Histopathological examination of heart reveals that myocardial degeneration, mononuclear cell infiltration was noticed in ISO treated rats, whereas the same was restored with esculetin treatment. In H9C2 cell lines esculetin could effectively reduced intracellular ROS inhibition and m-RNA expression of pro-inflammatory cytokines including TNF-a, IL-6 and NF-KB to prevent apoptosis or cell necrosis.
\end{abstract}

\footnotetext{
*Correspondence: samuelpharma@gmai.com; Vinod.kumar457@gmail.com

'Department of Pharmacology, Siddha Central Research Institute, Central

Council for Research in Siddha, Ministry of AYUSH, Govt of India, Chennai 600106, India

${ }^{3}$ Department of Pharmacology \& Toxicology, National Institute of Pharmaceutical Education and Research (NIPER), Hajipur 844102, India

Full list of author information is available at the end of the article
}

(c) The Author(s). 2021 Open Access This article is licensed under a Creative Commons Attribution 4.0 International License, which permits use, sharing, adaptation, distribution and reproduction in any medium or format, as long as you give appropriate credit to the original author(s) and the source, provide a link to the Creative Commons licence, and indicate if changes were made. The images or other third party material in this article are included in the article's Creative Commons licence, unless indicated otherwise in a credit line to the material. If material is not included in the article's Creative Commons licence and your intended use is not permitted by statutory regulation or exceeds the permitted use, you will need to obtain permission directly from the copyright holder. To view a copy of this licence, visit http://creativecommons.org/licenses/by/4.0/ The Creative Commons Public Domain Dedication waiver (http://creativecommons.org/publicdomain/zero/1.0/) applies to the data made available in this article, unless otherwise stated in a credit line to the data. 
Conclusion: The study provides the evidence of cardioprotective potentials of esculetin against isoproterenol induced myocardial infarction by antioxidant and myocardial membrane stabilization along with in vitro protection from arsenic induced ROS cell necrosis or apoptosis in H9C2 cells.

Keywords: Isoproterenol, Oxidative stress, Esculetin, Lysosomes, Antioxidant, Cardioprotection

\section{Background}

Cardiovascular diseases (CVDs) comprise disorders of the heart and blood vessels and still represent a major cause of death globally. CVDs have shown to be responsible for approximately 17.9 million deaths each year, which accounts for $31 \%$ of all deaths worldwide. Among the various CVDs, myocardial infarction (MI) is a major cause of mortality and morbidity across the world. Any blockade in the coronary artery leads to insufficient blood supply to heart, causing the heart muscle that is being supplied by the artery to get infarcted ultimately resulting in ischemic tissue necrosis in addition to other pathological and structural changes. The pathogenesis of MI includes hyperlipidemia, oxidative stress, peroxidation of membrane lipids, and loss of plasma membrane integrity [1].

Isoproterenol (ISO), a synthetic catecholamine and $\beta$ adrenergic agonist is well-known to cause severe stress in the myocardium by generating free radicals which in turn stimulates lipid peroxidation and perhaps the major contributing factor for the irreversible damage to the myocardial membrane [2]. ISO upon administration causes increase in heart rate leading to increased oxygen demand, high calcium burden and accumulation besides causing alterations in the morphology and membrane integrity of the myocardium with elevated cAMP levels in the myocardial cells [3].

Induction of myocardial infarction was previously performed by surgical procedures, but it has incidence of morbidity, mortality and animals were prone to pneumothorax infections [4]. Isoproterenol-induced myocardial infarction is simple and non-invasive model, considered as one of the most widely used experimental model to study the beneficial effects of many drugs and cardiac function [2] and it is similar to those pathophysiological changes observed in human myocardial infarction [5].

Natural products have high universal demands due to their claimed advantage in terms of both safety and efficacy against various diseases like MI. Plant based coumarins are low- molecular weight phenolic compounds that has been used for the prevention and treatment of various thromboembolism MI and stroke [6]. Esculetin (6, 7- di hydroxyl coumarin) is a natural coumarin derivative isolated from many plants such as Artemisia capillaries, Citrus limonia, Solanum surrettence and Euphorbia lathyris [7] with multiple pharmacological \& biochemical properties [8]. There is numerous treatment approaches that have been developed to attenuate the risk of myocardial infarction, but most of them fail when translated from the bench to the bedside. Therefore, there is a need to find new drugs which hostile MI as well as be used as suitable therapeutic candidate and also can be translated to clinical use in the future [9].

The present study was intended to investigate whether esculetin can provide protection against free radical generation by ISO and its associated alterations in the membrane bound enzymes and myocardial lysosomal enzyme activities in experimental rats. Further, we also tried to explore the probable mechanism of action of the esculetin for its cardio protection in $\mathrm{H} 9 \mathrm{C} 2$ cell lines.

\section{Experimental procedures Chemicals}

Isoproterenol (CAS Number 5984-95-2), and Esculetin (CAS Number 305-01-1) was purchased from Sigma Aldrich. Co, St. Louis, USA. All the chemicals used in the present study were of analytical grade and indigenous.

\section{In vitro studies}

\section{2, 2-Diphenyl-1-picrylhydrazyl (DPPH) radical scavenging activity}

The antioxidant activity of esculetin was measured using DPPH radical scavenger assay in triplicate. Concentration of $5,25,50$ and $100 \mu \mathrm{M} / \mathrm{mL}$ were used along with $10 \mu \mathrm{M}$ of ascorbic acid as reference standard. The test were then incubated with $50 \mu \mathrm{L}$ of $0.1 \mathrm{mM} \mathrm{DPPH}$ solution and made up to the final volume to $3 \mathrm{~mL}$ with methanol. A blank was prepared using DPPH solution and methanol. The reaction mixture was incubated for $30 \mathrm{~min}$ at room temperature in the dark followed by measuring absorbance at $517 \mathrm{~nm}$ [10].

\section{H9C2 cell culture}

H9C2 myoblast cells from rat's myocardium were acquired from National Centre for Cell Sciences, Pune, India. The myoblast cells were cultured in Dulbecco's modified Eagle's Medium (DMEM) medium supplemented with $10 \% \mathrm{FBS}$ and $10 \mathrm{ml} / 1100 \times$ antibiotic-antimycotic solution containing 10,000 units of penicillin and $10 \mathrm{mg} / \mathrm{ml}$ streptomycin in $0.9 \%$ normal saline in a humidified atmosphere of $95 \%$ air and $5 \% \mathrm{CO}_{2}$ at $37^{\circ} \mathrm{C}$. 


\section{Measurement of cell viability by MTT assay}

The cells were seeded in 96-well culture plates at a density of $7 \times 104$ cells/well. When the cells reached $80 \%$ confluence, they were treated with $1 \%$ dimethyl sulfoxide (DMSO) solution, and 5, 2550 and $100 \mu \mathrm{g} / \mathrm{mL}$ of esculetin at $37^{\circ} \mathrm{C}$ for $24 \mathrm{~h}$. The cells were then incubated with 3-(4,5-dimethylthiazol-2-yl)-2,5-diphenyltetrazolium bromide (MTT) $(0.5 \mathrm{mg} / \mathrm{mL})$ solution for $4 \mathrm{~h}$, and the resulting formazan was solubilized with $150 \mu \mathrm{L}$ of DMSO for $30 \mathrm{~min}$. The absorbance of each well was measured at $570 \mathrm{~nm}$, and the absorbance of control cells was considered to indicate $100 \%$ cell viability $[10,11]$. Scheme represented in Fig. 1.

\section{Intracellular reactive oxygen species (ROS) measurement}

The generation of intracellular reactive oxygen species (ROS) was measured by using the ROS-sensitive fluorescence indicator called Dichlorofluorescin diacetate (DCFH-DA) as per our previous protocol. H9C2 cells grown in 12 well plates $0.1 \times 10^{6}$ to $\sim 75 \%$ confluence were treated in triplicate. The cells were treated with esculetin at 25 and $50 \mu \mathrm{M} / \mathrm{mL}$ concentrations for $12 \mathrm{~h}$. After incubation, $10 \mu \mathrm{M}$ arsenic were added to esculetin treated wells and incubated for $2 \mathrm{~h}$ at $37^{\circ} \mathrm{C}$. All the wells including control were washed with PBS and incubated with $20 \mu \mathrm{M}$ DCFH-DA for $30 \mathrm{~min}$ at $37^{\circ} \mathrm{C}$ in the dark. After, Cells were washed, and analyzed by flow cytometer. The florescence intensity was calculated using the FAC Suite software [10]. Scheme represented in Fig. 1 .

RNA isolation, CDNA synthesis and qPCR to assess mRNA expression of TNF-a, IL-6, NF-kb

H9C2 cells grown in 12 well plates $0.1 \times 10^{6}$ to $\sim 75 \%$ confluence were treated in triplicate. After arsenic and esculetin treatment, the total RNA was isolated from H9C2 cells by using Trizol reagent (Thermo Fisher Scientific, Inc.). The isolated RNA was quantified by using a nano-drop spectrophotometer and complementary DNA (cDNA) was synthesized from $1 \mu \mathrm{g}$ of RNA was used for reverse transcription reaction using the iScript cDNA synthesis kit (Bio-Rad, Hercules, CA, USA). Reverse transcription quantitative polymerase chain reaction (RT-qPCR) was performed by using the SYBR green reagent according to the manufacturer's protocol (MilliporeSigma).

The primer sequences used for qPCR were as follows: TNF- $\alpha$ forward, 5' GAACTGGCAGAAGAGGCACT-3' and reverse, 5'-GGTCTGGGCCATAGAACTGA-3'; IL6 forward, 5'-CCGGAGAGGAGACTTCACAG-3' and reverse, 5'-CAG AATTGCCATTGCACA-3'; NF-kB forward 5'-CCCACACTATGGATTTCCTACTTATG G'-3 and reverse 5' CCAGCAGCATCTTCACGTCTC$3^{\prime}$. RT-qPCR reactions were performed under the conditions like, $50^{\circ} \mathrm{C}$ for $35 \mathrm{~min}, 85^{\circ} \mathrm{C}$ for $12 \mathrm{~min}$, followed by 60 cycles of $95^{\circ} \mathrm{C}$ for $23 \mathrm{~s}$ and $60^{\circ} \mathrm{C}$ for $1.5 \mathrm{~min}$. The A. MTT assay

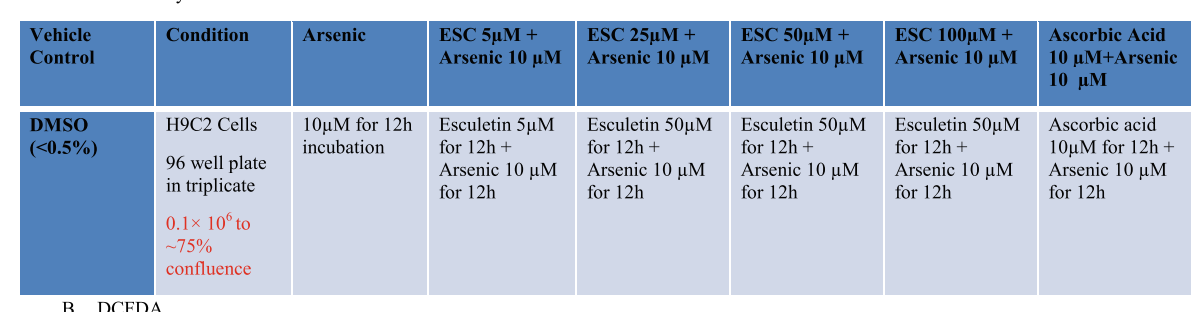

B. DCFDA
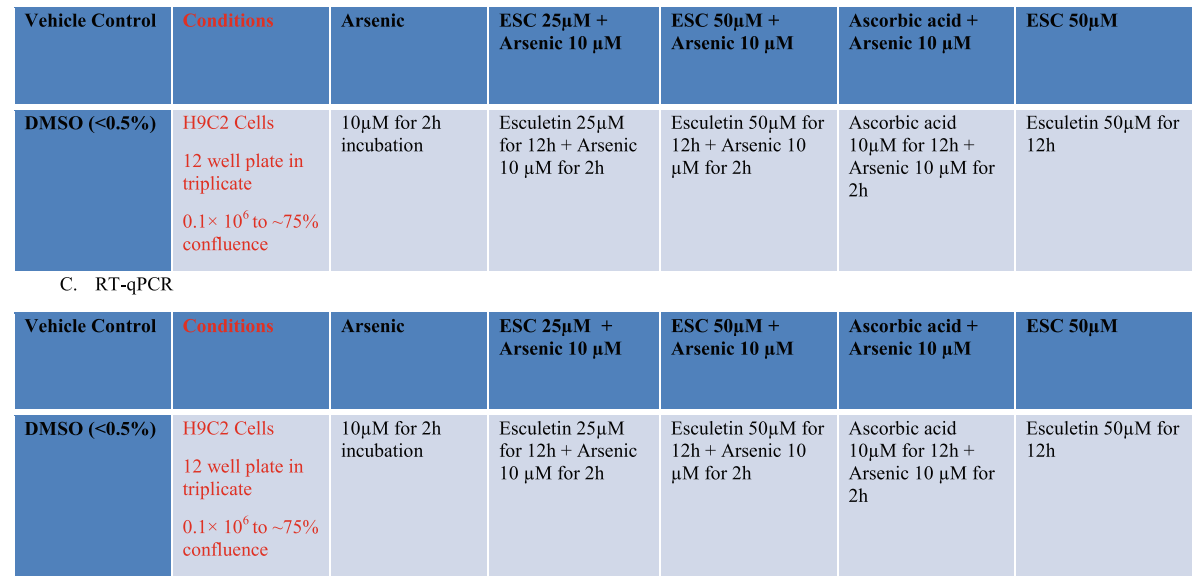

Fig. 1 Scheme for experimental design foe H9C2 cell line models A. MTT assay protocol. B. Protocol for DCFDA assay C. Protocol for TNF-a, IL-6 and NF-KB mRNA levels by using RT-qPCR method 
selected gene expression level was normalized to glyceraldehyde-3-phosphate dehydrogenase (GAPDH) forward, 5' CTTTGGTATCGTGGAAGG ACTC-3' and reverse, 5' GTAGAGGCAGGGATGATGTTCT-3' as internal loading control $[12,13]$. Scheme represented in Fig. 1.

\section{In vivo study}

Animals

Male wistar rats weighed between 230 and $280 \mathrm{~g}$ were used in this study. Rats were housed under standard conditions and fed with standard pellet with drinking water ad libitum. The animals were kept in polypropylene cages and maintained at a room temperature of $25 \pm 2{ }^{\circ} \mathrm{C}$ with $55 \pm 5 \%$ relative humidity and $12 \mathrm{~h}$ light/ dark cycle. The study was carried out in compliance with the ARRIVE (Animals in Research: Reporting In Vivo Experiments) guidelines ("Guide for the Care and Use of Laboratory Animals" (Institute of Laboratory Animal Resources, National Academic Press 1996; NIH publication number \#85-23, revised 1996). All experimental procedures and methods were approved by the Institutional Animal Ethical Committee (IAEC), Sri Padmavathi School of Pharmacy, constitute as per the directions of the Committee for the Purpose of Control and Supervision of Experiments on Animals (CPCSEA), India.

\section{Induction of myocardial infarction}

Myocardial infarction was induced by dissolving isoproterenol $(100 \mathrm{mg} / \mathrm{kg})$ in normal saline and injected subcutaneously to rats for last two consecutive days of the experimental schedule [14].

\section{Experimental schedule}

The treatment schedule was fixed for 28 days and the 24 rats were divided into four groups of six each. Same timing preferable morning 10 am to $10: 30$ a m was maintained while dosing every day.

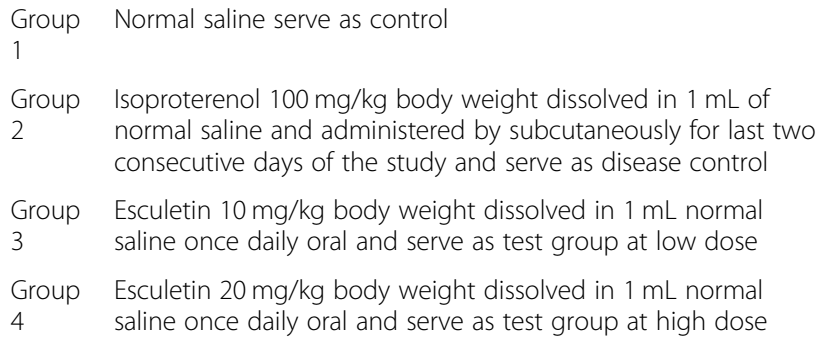

Group Esculetin $10 \mathrm{mg} / \mathrm{kg}$ body weight dissolved in $1 \mathrm{~mL}$ normal

3 saline once daily oral and serve as test group at low dose

Group Esculetin $20 \mathrm{mg} / \mathrm{kg}$ body weight dissolved in $1 \mathrm{~mL}$ normal $4 \quad$ saline once daily oral and serve as test group at high dose

\section{Blood sample collection and analysis}

At the end of treatment blood was collected from retro orbital plexus by anesthetizing the rats with thiopental sodium (35 mg/kg body weight, intra peritoneal) [15] and serum was separated by centrifugation at $2000 \mathrm{rpm}$.
Serum was used to analyze various biochemical parameters such as determinations of cardiac biomarkers lactate dehydrogenize (LDH), and creatinine kinase $\mathrm{MB}$ (CK-MB) by using commercial diagnostic kits (Agappe Pvt. Ltd., Kerala, India).

\section{$\mathrm{Na}^{+} / \mathrm{K}^{+}$ATPase activity of myocardial membrane}

The myocardial membrane $\mathrm{Na}^{+} / \mathrm{K}^{+}$ATPases activity was determined according to procedure done by Periyathambi and Ponnian 2007. The incubation mixture contained $10 \mathrm{mM}$ of Tris buffer, $20 \mathrm{mM}$ of potassium chloride, $125 \mathrm{mM}$ of sodium chloride, $1 \mathrm{mM}$ of EDTA and $3 \mathrm{mM}$ of ATP. To the incubation mixture, the reaction was initiated by the addition of $0.2 \mathrm{~mL}$ of tissue homogenate and the contents were incubated at $37^{\circ} \mathrm{C}$ for $15 \mathrm{~min}$. To stop the reaction of $10 \%$ trichloro acetic acid (TCA) was added. The tubes were centrifuged and supernatant was used for the estimation of liberated $P_{i}$. $1.0 \mathrm{~mL}$ of supernatant was made up to $4.3 \mathrm{~mL}$ with distilled water and added $1.0 \mathrm{ml} 3 \mathrm{mM}$ of ammonium molybdate reagent. The tubes were incubated at room temperature for $10 \mathrm{~min}$, and later $0.4 \mathrm{ml}$ of amino naptholsulphonic acid reagent was added to develop the color and the $P_{i}$ released recorded using a standard $P_{\mathrm{i}}$ graph [16].

\section{Preparation of lysosomal sub cellular fractions}

Lysosomal subcellular fractions were isolated according to the method of Venkatachalem et al.,2003. The heart tissue sample was cut open and placed in isotonic saline to remove the blood. Then the heart tissue was rinsed in ice cold $0.25 \mathrm{M}$ sucrose, blotted, weighed and minced. The enzyme extracts were prepared by homogenizing the tissue samples in $0.25 \mathrm{M}$ sucrose at $4{ }^{\circ} \mathrm{C}$. The portion of the homogenate was subjected to differential centrifugation, and the different fractions were separated as follows: structural proteins, nucleus, and cell debris at $600 \times \mathrm{g}$ for $10 \mathrm{~min}$; mitochondria at $5000 \times \mathrm{g}$ for $10 \mathrm{~min}$; lysosomes at $15,000 \times \mathrm{g}$ for $10 \mathrm{~min}$. Myocardial subfractions were treated with Triton X-100 (final concentration $0.2 \% \mathrm{v} / \mathrm{v}$ ) in ice for $15 \mathrm{~min}$ prior to the determination of enzymatic activity [17] .

The activities of the lysosomal enzymes including $\beta$ glucuronidase [18], $\beta$-glucosidase and $\beta$-galactosidase [19], and acid phosphatase [20] were determined.

\section{Determination of tissue antioxidants}

At the end of the experimentation hearts were excised from rats and homogenate in $0.1 \mathrm{M}$ Tris buffer ( $\mathrm{pH} 7.4)$ and the separated homogenates were used for estimation of heart antioxidants like super oxide dismutase (SOD) [21], Reduced glutathione (GSH) [22], Catalase [23] and lipid peroxidation (LPO) [24]. 


\section{Histopathological studies of heart}

After removal of myocardial tissue immediately washed with ice cold saline to remove all the blood and fixed in $10 \%$ buffered neutral formalin solution. After fixation was complete, tissues were embedded in paraffin and serial sections were cut in to $0.5 \mu \mathrm{m}$. Each section was stained with hematoxylin and eosin. The sections were examined under light microscope and histograms were taken.

\section{Statistical analysis}

Results were expressed as mean \pm standard error mean multiple comparisons of the significant analysis of variance (ANOVA) followed by the Dennett's test as post parametric test using computer based fitting program (Prism graph pad 5.0). A $p$ value of $<0.05$ was considered as statistically significant.

\section{Results}

\section{DPPH radical scavenging activity of esculetin}

Esculetin exhibited significant radical scavenging activity at all the working concentrations (Fig. 2) nevertheless, the maximum scavenging activity was at $50 \mu \mathrm{M}$ compared to control.

Esculetin inhibits intracellular ROS production in $\mathrm{H} 9 \mathrm{c} 2$ cell In the study, we investigated the inhibitory effect of esculetin on arsenic induced ROS generation in $\mathrm{H} 9 \mathrm{C} 2$ cells by using DCFH-DA a ROS sensitive nonfluorescent agent (Fig. 2). The DCF stained cells were analyzed by flow cytometer. During incubation period a significant ROS generation is noticed in cells placed with arsenic alone. Whereas cells treated with esculetin at 25 and $50 \mu \mathrm{g} / \mathrm{mL}$ concentrations exhibited dose-dependent inhibitory effects with $\mathrm{IC}_{50}$ value of $125 \mathrm{M}$.
Effect of esculetin on $\mathrm{H} 9 \mathrm{c} 2$ cell viability

MTT assay was used to determine the effect of esculetin on $\mathrm{H} 9 \mathrm{C} 2$ cell viability at $5,25,50$ and $100 \mu \mathrm{g} / \mathrm{mL}$ concentration. After the effective treatment with esculetin $\mathrm{H} 9 \mathrm{C} 2$ cells observed as viable with no significant cytotoxicity at all the concentrations (Fig. 3).

\section{Esculetin attenuates mRNA expression of TNF-a, IL- 6 , and} NF-KB against arsenic induced ROS in $\mathrm{H} 9 \mathrm{C} 2$ cells

The mRNA expression of pro-inflammatory cytokines TNF- $\alpha$, IL- 6 and NF- $\mathrm{BB}$ were measured using RT-qPCR method against arsenic induced ROS generation in $\mathrm{H} 9 \mathrm{C} 2$ cells (Fig. 4). The mRNA expression TNF- $\alpha$, IL- 6 and NF- $k B$ were significantly $(p \leq 0.05)$ elevated, approximately 9 folds compared to control cells. While the cells treated with esculetin at 25 and $50 \mu \mathrm{g} / \mathrm{mL}$ concentration in the presence of arsenic attenuated the expression of mRNA at 4 to 6 folds $(\mathrm{p} \leq 0.05)$ lesser than the control. No differences were observed in the levels of these proinflammatory cytokines between the control and esculetin alone groups.

\section{Effect of esculetin on cardiac biomarkers in ISO induced myocardial toxicity}

The alterations in serum heart biomarkers like CK$\mathrm{MB}$ and $\mathrm{LDH}$ were tabulated in Table 1 . The concentration of CK-MB and LDH were significantly $(p<$ $0.05)$ increased in isoproterenol alone treated rats compared to normal control rats. Animals treated with esculetin brought these cardiac markers near normalcy $(\mathrm{p}<0.05)$ compared to isoproterenol alone treated rats.
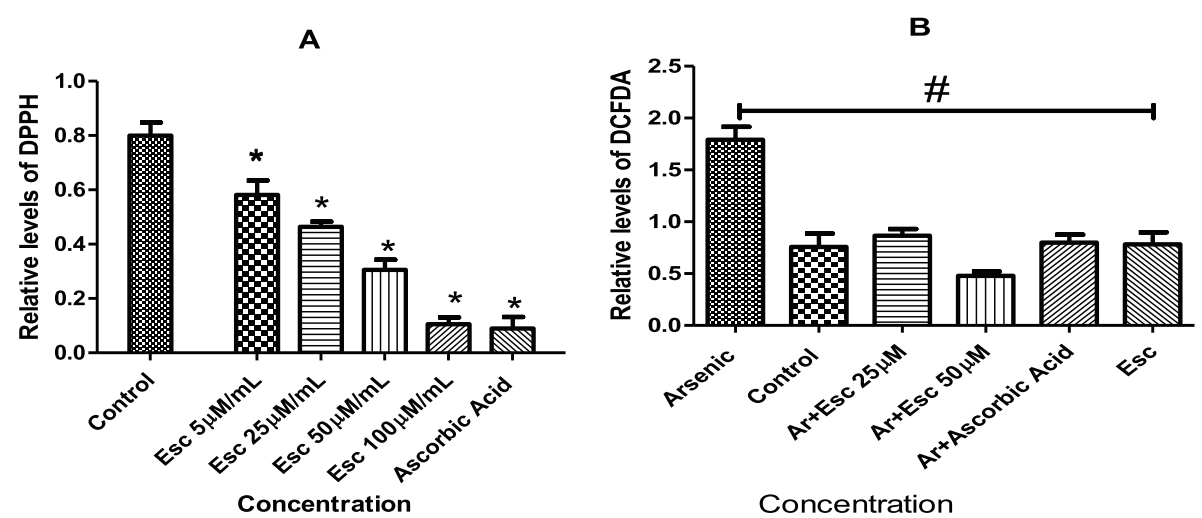

Fig. 2 Effect of esculetin on A) DPPH radical scavenging potentials of esculetin B) Fluorescence intensity of DCFDA, an indicator of ROS level was determined in $\mathrm{H} 9 \mathrm{C} 2$ cells. Cells were treated with Esculetin at 25 and $5025 \mu \mathrm{M}$ concentrations for $12 \mathrm{~h}$. Each concentration including control (arsenic) tested in triplicate with 75\% confluence. Values are presented as the mean \pm SEM. ${ }^{*}$ indicates $P<0.05$ when esculetin and ascorbic acid treatments compared to control. \# indicates $\mathrm{P}<0.05$ when esculetin, ascorbic acid and control treatments wells compared to Arsenic alone treated well 


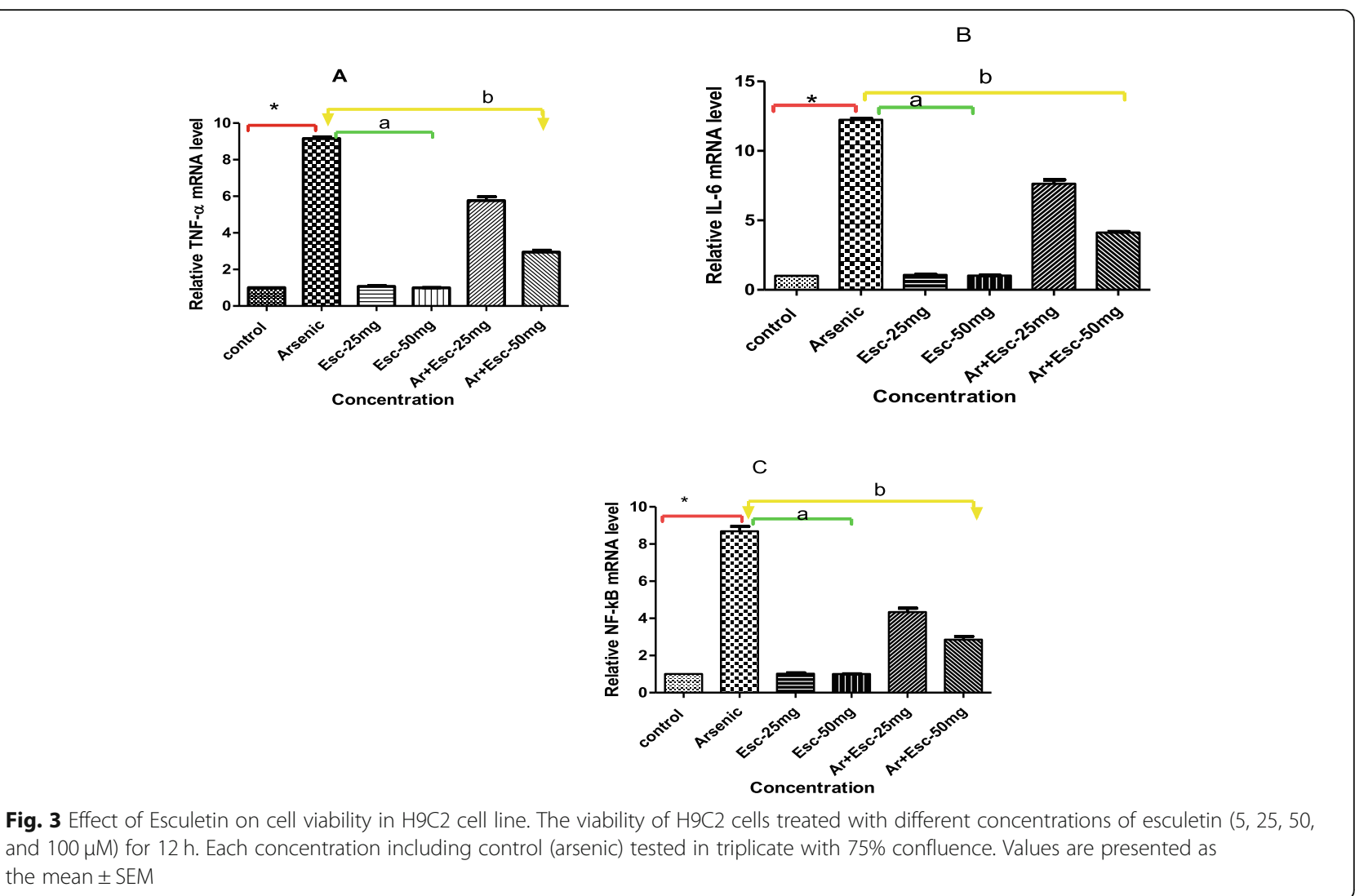

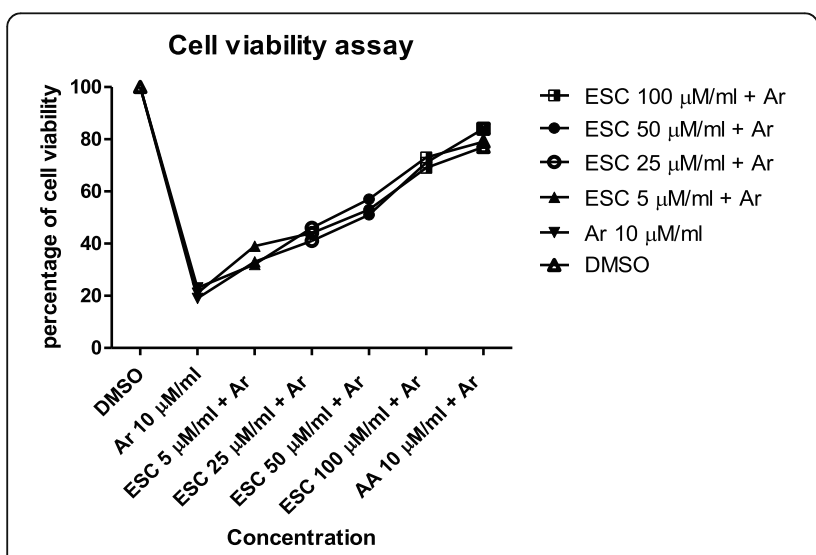

Fig. 4 Effect of Esculetin on mRNA expression levels against arsenic induced ROS in $\mathrm{H} 9 \mathrm{C} 2$ cells. Cells were treated with Esculetin at 25 and $5025 \mu \mathrm{M}$ concentrations for $12 \mathrm{~h}$. Each concentration including control (arsenic) tested in triplicate with 75\% confluence. The mRNA levels of pro-inflammatory markers (A) TNF-a, (B) IL-6 and (C) NF-KB were measured by using RT-qPCR. Values are presented as the mean \pm SEM. ${ }^{*} P<0.05$ when compared control with arsenic a $P<$ 0.001 when compared arsenic treatment with esculetin alone. $\mathrm{b} P<$ 0.005 when compared arsenic treatment with arsenic + esculetin
Effect of esculetin on membrane bound $\mathrm{Na}^{+} / \mathrm{K}^{+}$ATPase activity in ISO induced myocardial toxicity

The effect of Esculetin on membrane bound $\mathrm{Na}^{+} / \mathrm{K}^{+}$ ATPase activity has shown in Table 1 , significant $(p<$ $0.05)$ decrease of myocardial membrane bound $\mathrm{Na}^{+} /$ $\mathrm{K}^{+}$ATPase in rats treated with control when compared with normal rats. Whereas, the same $\mathrm{Na}^{+}$/ $\mathrm{K}^{+}$ATPase significantly $(\mathrm{p}<0.05)$ increased in rats pretreated with esculetin for 4 weeks when compared with control rats.

\section{Effect of Esculetin on lysosomal membrane destabilization in ISO induced myocardial toxicity}

Table 2, shows that alterations of activities of lysosomal hydrolases enzymes like $\beta$-glucuronidase, $\beta$ galactosidase, $\beta$-glucosidase, and acid phosphatase. Activity of these enzymes were significantly $(p<0.05)$ increased in heart tissue homogenates of rats treated with isoproterenol alone when compared with normal rats. Animals pre-treated with esculetin at doses of 10 and $20 \mathrm{mg} / \mathrm{kg}$ body weight for 28 days brought these enzyme activities significantly $(p<0.05)$ low and near to normal when compared with isoproterenol alone treated rats. 
Table 1 Esculetin effect on CK-MB, LDH and myocardial $\mathrm{Na}^{+} / \mathrm{K}^{+}$ATPase activity in ISO induced myocardial toxicity

\begin{tabular}{llll}
\hline & $\begin{array}{l}\text { CK-MB } \\
(\mathbf{I U} / \mathbf{L})\end{array}$ & $\begin{array}{l}\text { LDH } \\
(\mathbf{I U / L})\end{array}$ & $\mathbf{N a}^{+} \mathbf{K}^{+} \mathbf{A T P a s e s}$ activity $(\boldsymbol{\mu m o l ~ o f ~ P i / m g / h ) ~}$ \\
\hline Normal control & $85.14 \pm 4.374$ & $252.0 \pm 10.68$ & $3.285 \pm 0.2040$ \\
Disease control & $336.1 \pm 23.43^{\#}$ & $449.6 \pm 26.48^{\#}$ & $1.080 \pm 0.158^{\#}$ \\
Esculetin(10 mg/kg) & $144.4 \pm 6.399^{*}$ & $319.9 \pm 12.77^{*}$ & $2.190 \pm 0.099^{*}$ \\
Esculetin(20 mg/kg) & $121.6 \pm 7.470^{*}$ & $257.9 \pm 13.33^{*}$ & $2.542 \pm 0.303^{*}$ \\
\hline
\end{tabular}

All values are shown as mean \pm SEM and $n=6$. Data analysis done by one way analysis of variance followed by the Tukey multiple comparison tests. ${ }^{\#} p<0.05$, indicate disease control compared with normal. ${ }^{*} p<0.05$, indicate Esculetin treatment compared with disease control group

\section{Effect of esculetin on tissue antioxidants in ISO induced myocardial toxicity}

The changes in heart antioxidants are presented in Table 3. In ISO induced rats, there was a significant $(\mathrm{p}<$ 0.05) decrease in GSH, Catalase, SOD and a significant increase in LPO compared to normal control group and pre-treatment with esculetin at doses of 10 and $20 \mathrm{mg} /$ $\mathrm{kg}$, respectively, brought the elevated heart antioxidants near normal.

Histopathological observations (Fig. 5) of normal control rat's heart revealed normal cardiac muscle bundles without any inflammation, whereas myocardium of rats treated with isoproterenol alone has shown a marked inflammatory signs like membrane damage and cellular infiltration along with focal myonecrosis. Rats pre-treated with esculetin at doses of 10 and $20 \mathrm{mg} / \mathrm{kg}$ body weight has shown reduction in inflammatory signs and myonecrosis compared to disease control.

\section{Discussion}

The present study validates to reduce the acuteness of isoproterenol induced myocardial infarction by stabilizing the myocardial membrane integrity. The results of experiment bring a new outcome that, pretreatment with esculetin in experimental rats protects against myocardial infarction. Reactive oxygen species generation by oxidative stress plays an important role in the development of myocardial infarction both experimental and clinically [25].

Antioxidant compounds, especially polyphenol compounds from plants, are capable of counteracting the harmful effects caused by ROS and therefore it can prevent chronic diseases related to oxidative stress [26]. In the present study reveals that, esculetin has shown that direct radical quenching effect in DPPH radical scavenging assay. In addition, it also reduced the intracellular ROS production induced by arsenic [27] in $\mathrm{H} 9 \mathrm{C} 2$ cell lines. Treatment with esculetin in $\mathrm{H} 9 \mathrm{C} 2$ cells, a noticeable reduction of DCFDA fluorescence intensity was observed this indicates that, esculetin may interact with cellular anti-oxide enzymes. Thus, esculetin has the ability to alleviate free radicals ions both in vitro and in vivo. This was further confirms by tissue antioxidant data of present study.

Anti-oxidant enzymes such as catalase, superoxide dismutase (SOD), glutathione peroxidase and glutathione-S transferase (GSH) are the first line of cellular defense against oxidative injury by superoxide anion radical and $\mathrm{H}_{2} \mathrm{O}_{2}$ before interacting to form the more reactive hydroxyl radical [28]. Auto-oxidation of ISO produces highly cytotoxic free radicals like quinines which in addition with superoxide anion and potent hydroxyl radicals damages the polyunsaturated fatty acids of myocardial membrane $[29,30]$. The elevation of these free radicals brings an imbalance between tissue bound cellular scavenging enzymes like SOD, GSH and Catalase and lipid peroxidase [31].

The elevation of free radical including superoxide, hydroxyl ions and hydrogen peroxide ions was the reason for decreasing of tissue bound antioxidant enzymes [32, 33]. It is in line with previous studies, that tissue anti-oxidant enzymes were significantly decreased

Table 2 Esculetin effect on myocardial lysosomal enzyme's activity in ISO induced myocardial toxicity

\begin{tabular}{|c|c|c|c|c|}
\hline & $\begin{array}{l}\beta \text {-glucuronidase ( } \mathrm{p} \text {-nitro } \\
\text { phenol/h/mg protein) }\end{array}$ & $\begin{array}{l}\beta \text {-glucosidase (p-nitro } \\
\text { phenol/h/mg protein) }\end{array}$ & $\begin{array}{l}\beta \text {-galactosidase ( } \mathrm{p} \text {-nitro } \\
\mathrm{phenol} / \mathrm{h} / \mathrm{mg} \text { protein) }\end{array}$ & $\begin{array}{l}\text { Acid phosphatase (p-nitro } \\
\text { phenol/h/mg protein) }\end{array}$ \\
\hline Normal & $0.425 \pm 0.003$ & $0.050 \pm 0.003$ & $0.042 \pm 0.004$ & $0.071 \pm 0.008$ \\
\hline $\begin{array}{l}\text { Disease } \\
\text { Control }\end{array}$ & $0.088 \pm 0.007^{\#}$ & $0.114 \pm 0.003^{\#}$ & $0.107 \pm 0.007^{\#}$ & $0.159 \pm 0.009^{\#}$ \\
\hline $\begin{array}{l}\text { Esculetin }(10 \\
\mathrm{mg} / \mathrm{kg})\end{array}$ & $0.536 \pm 0.005^{*}$ & $0.063 \pm 0.005^{*}$ & $0.073 \pm 0.005^{*}$ & $0.084 \pm 0.005^{*}$ \\
\hline $\begin{array}{l}\text { Esculetin }(20 \\
\mathrm{mg} / \mathrm{kg})\end{array}$ & $0.42 \pm 0.001^{*}$ & $0.06 \pm 0.002^{*}$ & $0.062 \pm 0.001^{*}$ & $0.079 \pm 0.003^{*}$ \\
\hline
\end{tabular}

All values are shown as mean \pm SEM and $n=6$. Data analysis done by one way analysis of variance followed by the Tukey multiple comparison tests. ${ }^{\#} p<0.05$ indicate disease control compared with normal. ${ }^{*} p<0.05$, indicate Esculetin compared with disease control group 
Table 3 Esculetin effect on myocardial tissue antioxidant enzyme's activity in ISO induced myocardial toxicity

\begin{tabular}{lllll}
\hline & $\begin{array}{l}\text { SOD }(\mathbf{U} / \mathbf{m g} \\
\text { Protein) }\end{array}$ & $\begin{array}{l}\text { CATALASE }(\mu \mathrm{M} \text { H202Consumed/mg } \\
\text { Protein }\end{array}$ & $\begin{array}{l}\text { GSH }(\boldsymbol{\mu g} \text { of GSH/mg } \\
\text { Protein) }\end{array}$ & $\begin{array}{l}\text { LPO (nm of MDA/mg } \\
\text { Protein) }\end{array}$ \\
\hline Normal & $9.248 \pm 1.047$ & $7.965 \pm 1.217$ & $11.65 \pm 1.108$ & $1.693 \pm 0.200$ \\
Disease Control & $1.646 \pm 0.516^{\#}$ & $1.159 \pm 0.386^{\#}$ & $4.027 \pm 0.784^{\#}$ & $3.313 \pm 0.407^{\#}$ \\
$\begin{array}{l}\text { Esculetin(10 mg/ } \\
\text { kg) }\end{array}$ & $5.804 \pm 0.267^{*}$ & $6.484 \pm 1.145^{*}$ & $7.766 \pm 0.384^{*}$ & $2.044 \pm 0.255^{*}$ \\
$\begin{array}{l}\text { Esculetin(20 mg/ } \\
\text { kg) }\end{array}$ & $7.241 \pm 1.070^{*}$ & $9.249 \pm 1.856^{*}$ & & $1.661 \pm 0.365^{*}$
\end{tabular}

All values are shown as mean \pm SEM and $n=6$. Data analysis done by one way analysis of variance followed by the Tukey multiple comparison tests. ${ }^{\#} p<0.05$, indicate disease control compared with normal. ${ }^{* *} p<0.05$, indicate Esculetin compared with disease control group

where the LPO levels were increased in the hearts of ISO alone treated rats $[34,35]$. Pre-treatment with esculetin brought the elevated levels of tissue anti-oxidant enzymes like SOD, GSH and Catalase near base line. Our results are agreement with several previous findings in which esculetin is a potential naturally occurring antioxidant both in vitro and in vivo $[36,37]$.

Probably, the anti-oxidant effect of esculetin could by hydrogen donating ability of esculetin [38], the catechol structure of esculetin contributes the stronger antioxidant activity [36]. The available data of the present study confirms with existing literature that, esculetin has the ability to activate anti-oxidant enzymes or and might combat the excess ROS formed with in the cell $[39,40]$.

Arsenic one of the major component to induce intracellular ROS [27]. Cytokines such as IL-1 $\beta$, TNF- $\alpha$ and IL-6 are pro-inflammatory markers play a vital role in various inflammatory pathways like JNK, NF-kB and
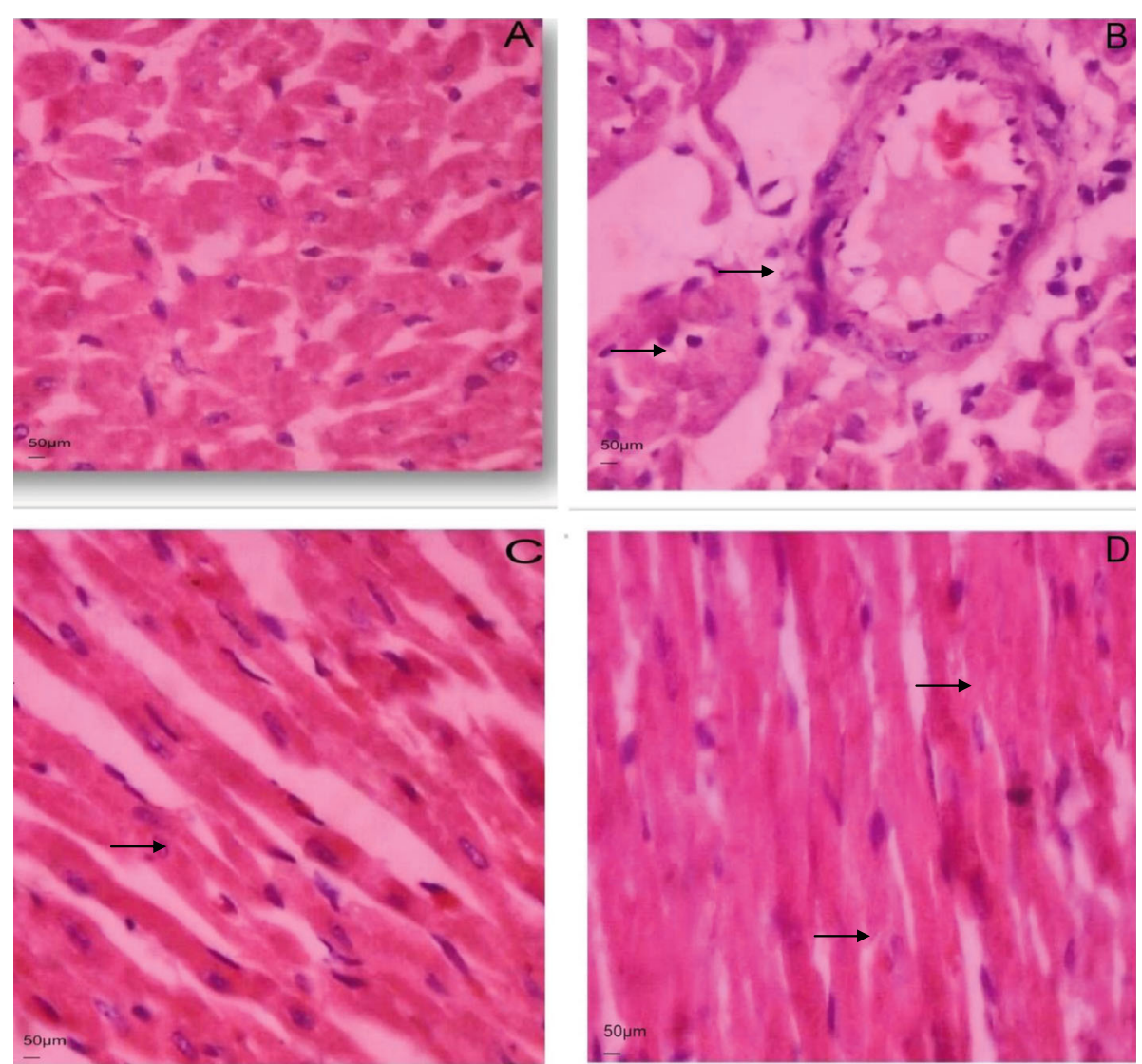

Fig. 5 (A-D): Histopathological study of the heart. A): Normal control rat's heart showing normal texture of cardiac muscle bundles. B) ISO induced MI rat's heart showing area of infarction with inflammatory cell infiltration, cardiac necrosis and splitting of muscle bundles. C\&D) pretreatment with esculetin showing the prevention of cell infiltration, splitting of muscle bundle by ISO has been prevented 
NLRP [41]. NF- $\mathrm{kB}$ is a multiple transcription factor that regulates transcription of various genes involved in the pathogenesis of myocardial infarction like TNF- $\alpha$ and IL-6 [42, 43]. These pro-inflammatory cytokines and inflammatory signaling pathways could promote the development of myocardial infarction. Intracellular ROS promotes the production and release of these proinflammatory cytokines from cardiomyocytes. TNF- $\alpha$, IL-1b, and IL-6, are early predictors of organ dysfunction and, causes to activate cardiomyocytes apoptosis [44]. In our study we investigated for the change in the mRNA expression levels of ROS sensitive transcription factor $\mathrm{NF}-\mathrm{kB}$ along with its pro-inflammatory cytokines TNF- $\alpha$ and IL-6 in esculetin treated $\mathrm{H} 9 \mathrm{C} 2$ cells and noticed a dose dependent decline in the mRNA expressions of above said markers. This denotes that esculetin could effectively inhibited the expression of mRNAs of proinflammatory cytokines, which are the prominent markers of inflammation and myocardial toxicity, this effect may prevent the $\mathrm{H} 9 \mathrm{C} 2$ cell to undergo apoptosis or cell necrosis from arsenic induced ROS. The present findings are in line with earlier research saying esculetin could effectively down regulated the TNF- $\alpha$, NF- $\mathrm{KB}$ and IL-6 levels upon various stimulus including ROS [13, 45, 46].

CK-MB and LDH are indicator biomarker to diagnose the severity of myocardial infarction and number of necrotic cells [47]. These enzymes are present in cardiac muscle, upon the injury release into the blood stream [48]. The available data $[49,50]$, revels that isoproterenol administration significantly elevates the CK-MB and LDH levels in the serum; in the present study also the same. In the in vitro model [28], esculetin improved the cell viability and reduces the release of $\mathrm{LDH}$, in the same line, pre-treatment with esculetin reduce the ISO induced raise of CK-MB and LDH in rats to protect the myocardium, and it also maintained the cell viability in arsenic induced stress $\mathrm{H} 9 \mathrm{C} 2$ cell lines. This implying that esculetin has the potentiality to protect pathological and morphological changes in the rats in a dose-independent manner.

The functioning ability of the membrane bound enzymes are depends on the stability of plasma membrane. Under normal cell physiology $\mathrm{Na}^{+}-\mathrm{K}^{+}$ ATPase will balances the $\mathrm{Na}^{+}$and $\mathrm{K}^{+}$ions across the membrane, upon its disruption may leads to ionic inequality and cell death. Therefore, the determination of membrane bound enzyme activities will indicate any alteration to the membrane physiology under pathological conditions [51]. ISO liberated free radicals bind to the membrane lipids to cause injure, thereby inhibits the membrane associated enzymes function including ATPases [2]. The loss of ATPase activity in the ischemic state may be responsible for causing functional damage and reversible necrotic changes in the involved myocardial cell [52].

Palanivel Karthika et al., has found that, pre-treatment with esculetin has effectively increased the $\mathrm{Na}^{+}-\mathrm{K}^{+}$ ATPase activity, this could be due to the ability of esculetin to protect $\mathrm{SH}$ group of $\mathrm{Na}^{+}-\mathrm{K}^{+}$ATPase enzyme from oxidative damage through inhibition of peroxidation of membrane lipids [53]. It is in line that, the same circumstances were observed in the present study with pre-treatment with esculetin appreciably restored the membrane bound $\mathrm{Na}^{+}-\mathrm{K}^{+}$ATPase near to normalcy.

Lysosomes are surrounded by phospholipid enriched membranes, and are a potential site for free-radical attack including ISO produces quinines [54]. Therefore, radical ions causing to loss the membrane stability and leads the release of hydrolytic enzymes from its sacs to augments cell necrosis $[55,56]$. Hence, significant attention has been raised on the involvement of lysosomal enzymes in myocardial damage. From our previous report it was observed that, administration of the ISO to the rats causes a significant elevation in the activities of the lysosomal enzymes [30]. In the present study same effect observed.

Stabilization of myocardial cell membranes, mainly the lysosomal membranes, may extend the viability of myocardial cells to prevent MI. Pre-treatment with esculetin could effectively inhibit the release of lysosomal enzymes from their sacs, and protects the myocardium from necrosis. This provides the first in vivo evidence that esculetin protects myocardial from ISO-induced injury by lysosomal membrane stabilization.

From in vivo study the biochemical finding that proves the esculetin's protection in rat's myocardium was further supported by histopathological examination. Myocardial tissue sections of normal rats depicted clear integrity of the myocardial cell membrane whereas the sections of hearts treated with ISO showed necrosis of muscle fibers with inflammatory cell infiltration, edema and fragmentation of muscle fibers, which indicated involvement of oxidative stress and inflammatory processes. Pre-treatment with esculetin showed the integrity to the structure of myocardium from ISO injury near to the normal myocardium denotes its cardio protective action. The limitation of the study was a clear mechanism of action by which pathway esculetin interfering to reducing the myocardial necrosis has not done.

\section{Conclusion}

Based on the results of this study, it can be concluded that esculetin ameliorates isoproterenol associated pathological features like attenuating the oxidative stress, stabilization of lysosomal, myocardial membrane in the protection of rat's myocardium. Further, esculetin could effectively down regulates pro-inflammatory 
markers TNF- $\alpha$, NF- $\kappa B$ and IL- 6 cytokines from the arsenic induced ROS to prevent $\mathrm{H} 9 \mathrm{C} 2$ cells to undergo necrosis or death. Understanding the molecular mechanisms involved in the lysosomal enzyme leakage may prove beneficial measures in the prevention of myocardial infarction or toxicity. Thus, esculetin may consider as a potential therapeutic candidate to prevent myocardial toxicity. Further work need to be done in order to establish specific molecular mechanisms by which esculetin prevent myocardial toxicity or infarction and possibility for its clinical application.

\section{Abbreviations \\ CVDs: Cardiovascular diseases; MI: Myocardial infarction; ISO: Isoproterenol; TNF-a : Tumor necrosis factor alfa; IL-6: Including interleukin-6; NF-kB: Nuclear factor kappa B; NLRP3: Nucleotide-binding Leucine-rich repeat Receptors Pro- tein DMEMDulbecco's Modified Eagle's Medium; DMSO: Dimethyl sulfoxide; ROS: Intracellular reactive oxygen species; DCFH-DA: Dichlorofluorescin diacetate; cDNA: complementary DNA; RT-qPCR: Reverse transcription quantitative polymerase chain reaction; LDH: Lactate dehydrogenize; CK- MB: Creatinine kinase MB; TCA: Trichloro acetic acid; SOD: Super oxide dismutase; GSH: Reduced glutathione; LPO: Lipid peroxidation; mRNA: Messenger ribonucleic acid}

\section{Acknowledgements}

Authors are thankful to principal Prof Ranganayakulu D and management of Sri Padmavathi School of Pharmacy, Tirupati-517503, for providing the animal house and laboratory facilities. Authors would like to thank Dr Sigin Lal Jabaris, Research Officer, Department of Pharmacology, Siddha Central Researchlnstitute, for his help in the technical correction of manuscript.

\section{Authors' contributions}

CPP conceptualized, designed the study and prepared the manuscript and made the critical revisions, VKN performed all in vitro and cell line work and in the preparation of manuscript and involved in addressing the revisions SR performed animal activities and biochemical assays acquiring the data, NKGV analyzed the data and results interpretation and TK edited the complete manuscript and made ready for communication. The author(s) read and approved the final manuscript.

\section{Funding}

Not applicable.

\section{Availability of data and materials}

Corresponding author will provide the data used in present work upon the request.

\section{Declarations}

\section{Ethics approval and declaration}

All methods including animal experimental procedures were adopted in the study were performed in accordance with ARRIVE guidelines. Animal experimental protocols used in the present study were approved by Institutional Animal Ethical Committee of Sri Padmavathi School of Pharmacy (SPSP/CPCSEA/IAEC-1016/a /2015/009), constitute as per the directions of the Committee for the Purpose of Control and Supervision of Experiments on Animals (CPCSEA), India. The further methods and procedures adopted in the study are in agreement with appropriate guidelines and regulations.

\section{Consent for publication}

Not applicable.

\section{Competing interests}

The authors declare that they have no competing interest.

\section{Author details}

'Department of Pharmacology, Siddha Central Research Institute, Central Council for Research in Siddha, Ministry of AYUSH, Govt of India, Chennai
600106, India. ${ }^{2}$ Department of Biochemistry and College of Pharmaceutical Sciences, S V University, Tirupati 517502, India. ${ }^{3}$ Department of Pharmacology \& Toxicology, National Institute of Pharmaceutical Education and Research (NIPER), Hajipur 844102, India. ${ }^{4}$ Department of Pharmacology, Sri Padmavathi School of Pharmacy, Tirupati 517503, India. ${ }^{5}$ Department of Pharmacology, Dr Anjali Chatterjee Regional Institute of Homeopathy, Kolkata 700035, India.

Received: 1 March 2021 Accepted: 27 May 2021

Published online: 15 July 2021

\section{References}

1. Zaki AA, Hashish NE, Amer MA, Lahloub MF. Cardioprotective and antioxidant effects of oleogum resin "Olibanum" from Bos Boswellia carteri Birdw. (Bursearceae). Chin J Nat Med. 2014;12(5):345-50. https://doi.org/10.1 016/S1875-5364(14)60042-X.

2. Lobo RO, Chandrasekhar Sagar BK, Shenoy CK. Bio-tea prevents membrane destabilization during isoproterenol-induced myocardial injury. J Microscopy Ultrastructure. 2017;5(3):146-54. https://doi.org/10.1016/j.jmau.2016.09.001.

3. Eltobshy SAG, Hussein AM, Elmileegy AA, Askar MH, Khater Y, Metias EF, et al. Effects of heme oxygenase-1 upregulation on isoproterenol-induced myocardial infarction. Korean J Physiol Pharmacol. 2019;23(3):203-17. https://doi.org/10.4196/kjpp.2019.23.3.203.

4. Wong ZW, Thanikachalam PV, Ramamurthy S: Molecular understanding of the protective role of natural products on isoproterenol-induced myocardial infarction: A review. Biomed Pharmacother 2017, 94:1145-1166.

5. Rona G, Chappel Cl, Balazs T, Gaudry R. An infarct-like myocardial lesion and other toxic manifestations produced by isoproterenol in the rat. AMA Arch Pathol. 1959;67:443-55.

6. Voora D, McLeod HL, Eby C, Gage BF. The pharmacogenetics of coumarin therapy. Pharmacogenomics. 2005;6(5):503-13. https://doi.org/10.2217/14 622416.6.5.503.

7. Masamoto Y, Ando H, Murata Y, Shimoishi Y, Tada M, Takahata K. Mushroom tyrosinase inhibitory activity of esculetin isolated from seeds of Euphorbia lathyris L. Biosci Biotechnol Biochem. 2003;67(3):631-4. https:// doi.org/10.1271/bbb.67.631.

8. Jeon YJ, Jang JY, Shim JH, Myung PK, Chae Jl. Esculetin, a Coumarin derivative, exhibits anti-proliferative and pro-apoptotic activity in G361 human malignant melanoma. J Cancer Prevention. 2015;20(2):106-12. https://doi.org/10.15430/JCP.2015.20.2.106.

9. Schreiber T, Salhöfer L, Quinting T, Fandrey J. Things get broken: the hypoxia-inducible factor prolyl hydroxylases in ischemic heart disease. Basic Res Cardiol. 2019;114(3):16. https://doi.org/10.1007/s00395-019-0725-2.

10. Nelson VK, Ali A, Dutta N, Ghosh S, Jana M, Ganguli A, et al. Azadiradione ameliorates polyglutamine expansion disease in Drosophila by potentiating DNA binding activity of heat shock factor 1. Oncotarget. 2016;7(48):7828196. https://doi.org/10.18632/oncotarget.12930.

11. Nelson VK, Sahoo NK, Sahu M, Sudhan HH, Pullaiah CP, Muralikrishna KS. In vitro anticancer activity of Eclipta alba whole plant extract on colon cancer cell HCT-116. BMC Complement Med Therapies. 2020;20(1):355. https://doi. org/10.1186/s12906-020-03118-9.

12. Singh BK, Vatsa N, Nelson VK, Kumar V, Kumar SS, Mandal SC, et al. Azadiradione restores protein quality control and ameliorates the disease pathogenesis in a mouse model of Huntington's disease. Mol Neurobiol. 2018;55(8):6337-46. https://doi.org/10.1007/s1 2035-017-0853-3.

13. Choi RY, Ham JR, Lee MK. Esculetin prevents non-alcoholic fatty liver in diabetic mice fed high-fat diet. Chem Biol Interact. 2016;260:13-21. https:// doi.org/10.1016/j.cbi.2016.10.013.

14. Stanely Mainzen Prince P, Priscilla H, Devika PT: Gallic acid prevents lysosomal damage in isoproterenol induced cardiotoxicity in Wistar rats. Eur J Pharmacol 2009, 615:139-143, 1-3, DOl: https://doi.org/10.1016/j.ejphar.2009.05.003.

15. Prabhu S, Narayan S, Devi CS. Mechanism of protective action of mangiferin on suppression of inflammatory response and lysosomal instability in rat model of myocardial infarction. Phytotherapy Res. 2009;23(6):756-60. https://doi.org/10.1002/ptr.2549.

16. Devika PT. Mainzen Prince PS: (-)-epigallocatechin gallate (EGCG) prevents isoprenaline-induced cardiac marker enzymes and membrane-bound ATPases. J Pharm Pharmacol. 2008;60(1):125-33. https://doi.org/10.1211/jpp. 60.1.0016.

17. Sathish V, Ebenezar KK, Devaki T: Synergistic effect of nicorandil and amlodipine on lysosomal hydrolases during experimental myocardial infarction in rats. Biomed Pharmacotherapy 2003, 57:309-313. 
18. Hultberg B, Lindsten J, Sjöblad S. Molecular forms and activities of glycosidases in cultures of amniotic-fluid cells. Biochemical J. 1976;155(3): 599-605. https://doi.org/10.1042/bj1550599.

19. Conchie J, Levvy GA. Inhibition of glycosidases by aldonolactones of corresponding configuration. Biochemical J. 1957;65(2):389-95. https://doi. org/10.1042/bj0650389.

20. Kavanagh JP, Bardsley WG. The identity of the acid and alkaline phosphatases of human seminal plasma. J Reprod Fertil. 1979;57(1):43-8. https://doi.org/10.1530/jrf.0.0570043.

21. Misra HP, Fridovich I. The role of superoxide anion in the autoxidation of epinephrine and a simple assay for superoxide dismutase. J Biol Chem. 1972;247(10):3170-5. https://doi.org/10.1016/S0021-9258(19)45228-9.

22. Moron MS, Depierre JW, Mannervik B. Levels of glutathione, glutathione reductase and glutathione S-transferase activities in rat lung and liver. Biochim Biophys Acta. 1979;582(1):67-78. https://doi.org/10.1016/0304-4165(79)90289-7.

23. Aebi H. Catalase in vitro. Methods Enzymol. 1984;105:121-6. https://doi. org/10.1016/S0076-6879(84)05016-3.

24. Kovachich GB, Mishra OP. Lipid peroxidation in rat brain cortical slices as measured by the thiobarbituric acid test. J Neurochem. 1980;35(6):1449-52. https://doi.org/10.1111/j.1471-4159.1980.tb09022.x.

25. D'Oria R, Schipani R, Leonardini A, Natalicchio A, Perrini S, Cignarelli A, et al. The role of oxidative stress in cardiac disease: from physiological response to injury factor. Oxidative Med Cell Longev. 2020;2020:5732956.

26. Witaicenis A, Seito LN, da Silveira Chagas A, de Almeida LD, Jr., Luchini AC Rodrigues-Orsi P, Cestari SH, Di Stasi LC: Antioxidant and intestinal antiinflammatory effects of plant-derived coumarin derivatives. Phytomedicine 2014, 21:240-246, 3, DOl: https://doi.org/10.1016/j.phymed.2013.09.001.

27. Chowdhury R, Chatterjee R, Giri AK, Mandal C, Chaudhuri K. Arsenic-induced cell proliferation is associated with enhanced ROS generation, Erk signaling and CyclinA expression. Toxicol Lett. 2010;198(2):263-71. https://doi.org/10.1 016/j.toxlet.2010.07.006.

28. He Y, Li C, Ma Q, Chen S. Esculetin inhibits oxidative stress and apoptosis in H9c2 cardiomyocytes following hypoxia/reoxygenation injury. Biochem Biophys Res Commun. 2018:501(1):139-44. https://doi.org/10.1016/j.bbrc.2018.04.195.

29. Priscilla DH, Prince PS. Cardioprotective effect of gallic acid on cardiac troponinT, cardiac marker enzymes, lipid peroxidation products and antioxidants in experimentally induced myocardial infarction in Wistar rats. Chem Biol Interact. 2009:179(2-3):118-24. https://doi.org/10.1016/j.cbi.2008.12.012

30. Pullaiah CP, Kumar GN, Jyothsna K, Thyagaraju K, Nelson VK, Reddy GDJOP, Medicine E: Rosa damascena Mill L attenuates myocardial lysosomal membrane destabilization in isoproterenol induced oxidative stress 2017, 17:373-380.

31. Shahzad S, Mateen S, Mubeena Mariyath PM, Naeem SS, Akhtar K, Rizvi W, Moin S: Protective effect of syringaldehyde on biomolecular oxidation, inflammation and histopathological alterations in isoproterenol induced cardiotoxicity in rats. Biomedicine Pharmacotherapy 2018, 108:625-633.

32. S M, Shaik AH, E MP, Al Omar SY, Mohammad A, Kodidhela LD: Combined cardio-protective ability of syringic acid and resveratrol against isoproterenol induced cardio-toxicity in rats via attenuating NF-kB and TNF-a pathways. Sci Rep 2020, 10:3426, 1, DOl: https://doi.org/10.1038/s41598-020-59925-0.

33. Fang WJ, Wang CJ, He Y, Zhou YL, Peng XD, Liu SK. Resveratrol alleviates diabetic cardiomyopathy in rats by improving mitochondrial function through PGC-1a deacetylation. Acta Pharmacol Sin. 2018;39(1):59-73. https://doi.org/10.1038/aps.2017.50.

34. Anandan R, Chatterjee NS, Sivakumar R, Mathew S, Asha KK, Ganesan B. Dietary chitosan supplementation ameliorates isoproterenol-induced aberrations in membrane-bound ATPases and mineral status of rat myocardium. Biol Trace Elem Res. 2015;167(1):103-9. https://doi.org/10.1 007/s12011-015-0289-4.

35. Tao W, Zuo T, Ma C, Long H. Suppressing receptor-interacting protein 140: a new sight for esculetin to treat myocardial ischemia/reperfusion injury. RSC Adv. 2016;6

36. Kim SH, Kang KA, Zhang R, Piao MJ, Ko DO, Wang ZH, et al. Protective effect of esculetin against oxidative stress-induced cell damage via scavenging reactive oxygen species. Acta Pharmacol Sin. 2008;29(11):1319-26. https:// doi.org/10.1111/j.1745-7254.2008.00878.x.

37. Lee BC, Lee SY, Lee HJ, Sim GS, Kim JH, Kim JH, et al. Anti-oxidative and photo-protective effects of coumarins isolated from Fraxinus chinensis. Arch Pharm Res. 2007;30(10):1293-301. https://doi.org/10.1007/BF02980270.

38. Wang $K$, Zhang Y, Ekunwe S, Yi X, Liu X, Wang H. Pan Y-m: antioxidant activity and inhibition effect on the growth of human colon carcinoma (HT-
29) cells of esculetin from cortex Fraxini. Med Chem Res. 2011;20(7):968-74. https://doi.org/10.1007/s00044-010-9426-y.

39. Arora R, Sawney S, Saini V, Steffi C, Tiwari M, Saluja D. Esculetin induces antiproliferative and apoptotic response in pancreatic cancer cells by directly binding to KEAP1. Mol Cancer. 2016;15(1):64. https://doi.org/10.11 86/s12943-016-0550-2.

40. Han MH, Park C, Lee DS, Hong SH, Choi IW, Kim GY, et al. Cytoprotective effects of esculetin against oxidative stress are associated with the upregulation of Nrf2-mediated NQO1 expression via the activation of the ERK pathway. Int J Mol Med. 2017:39(2):380-6. https://doi.org/10.3892/ijmm.2016.2834.

41. Mangali S, Bhat A, Udumula MP, Dhar I, Sriram D, Dhar A. Inhibition of protein kinase $R$ protects against palmitic acid-induced inflammation, oxidative stress, and apoptosis through the JNK/NF-kB/NLRP3 pathway in cultured H9C2 cardiomyocytes. J Cell Biochem. 2019;120(3):3651-63. https:// doi.org/10.1002/jcb.27643.

42. Jin JL, LV RG, Guo J, Liu XH, Liang YW, Wei JR, et al. Improvement of left ventricular Remodelling by inhibition of NF-KB in a rat model of myocardial infarction. Heart Lung Circulation. 2016;25(10):1007-12. https://doi.org/10.1 016/j.hlc.2015.11.005

43. Ma L, Sun P, Zhang JC, Zhang Q, Yao SL. Proinflammatory effects of S100A8/A9 via TLR4 and RAGE signaling pathways in BV-2 microglial cells. Int J Mol Med. 2017:40(1):31-8. https://doi.org/10.3892/ijmm.2017.2987.

44. Zhang S, Zhang Y. Isoflurane reduces endotoxin-induced oxidative, inflammatory, and apoptotic responses in H9c2 cardiomyocytes. Eur Rev Med Pharmacol Sci. 2018;22(12):3976-87. https://doi.org/10.26355/eurrev_2 01806 15282

45. Zhu X, Gu J, Qian H. Esculetin attenuates the growth of lung Cancer by downregulating Wnt targeted genes and suppressing NF-KB. Archivos de Bronconeumologia. 2018;54(3):128-33. https://doi.org/10.1016/j.arbres.2017. 09.005 .

46. Chen T, Guo Q, Wang H, Zhang H, Wang C, Zhang P, et al. Effects of esculetin on lipopolysaccharide (LPS)-induced acute lung injury via regulation of RhoA rho kinase/NF-kB pathways in vivo and in vitro. Free Radic Res. 2015;49(12): 1459-68. https://doi.org/10.3109/10715762.2015.1087643.

47. Geetha A, Sankar R, Marar T, Devi CS. Alpha-tocopherol reduces doxorubicin-induced toxicity in rats--histological and biochemical evidences. Indian J Physiol Pharmacol. 1990;34(2):94-100

48. Li Y, Feng J, Mo Y, Liu H, Yang B. Concordance between cardio-protective effect on isoproterenol-induced acute myocardial ischemia and phenolic content of different extracts of Curcuma aromatica. Pharm Biol. 2016;54(12): 3226-31. https://doi.org/10.1080/13880209.2016.1216134.

49. Yates JC, Dhalla NS. Induction of necrosis and failure in the isolated perfused rat heart with oxidized isoproterenol. J Mol Cell Cardiol. 1975;7(11): 807-16. https://doi.org/10.1016/0022-2828(75)90132-7.

50. Rajadurai M, Prince PS. Preventive effect of naringin on isoproterenolinduced cardiotoxicity in Wistar rats: an in vivo and in vitro study. Toxicology. 2007;232(3):216-25. https://doi.org/10.1016/j.tox.2007.01.006

51. Brindha $E$, Rajasekapandiyan M. Preventive effect of phytic acid on lysosomal hydrolases in normal and isoproterenol-induced myocardial infarction in Wistar rats. Toxicol Mech Methods. 2015;25(2):150-4. https:// doi.org/10.3109/15376516.2014.1003421

52. Dhivya V, Priya LB, Chirayil HT, Sathiskumar S, Huang CY, Padma W: Piperine modulates isoproterenol induced myocardial ischemia through antioxidant and anti-dyslipidemic effect in male Wistar rats. Biomed Pharmacother 2017, 87:705-713.

53. Karthika P, Rajadurai M, Ganapathy P, Kanchana GJJPR: Preventive effect of esculetin on lipid peroxides and antioxidants in isoproterenol-induced myocardial infarction in Wistar rats 2012, 5:915-918.

54. Roy SJ. Stanely Mainzen Prince P: protective effects of sinapic acid on lysosomal dysfunction in isoproterenol induced myocardial infarcted rats. Food Chem Toxicol. 2012;50(11):3984-9. https://doi.org/10.1016/j.fct.2012.08.017.

55. George J: Elevated serum beta-glucuronidase reflects hepatic lysosomal fragility following toxic liver injury in rats. Biochemistry Cell Biol 2008, 86: 235-243.

56. Karthikeyan K, Sarala Bai BR, Niranjali Devaraj S. Grape seed proanthocyanidins ameliorates isoproterenol-induced myocardial injury in rats by stabilizing mitochondrial and lysosomal enzymes: an in vivo study. Life Sci. 2007;81(23-24):1615-21. https://doi.org/10.1016/j.lfs.2007.09.033.

\section{Publisher's Note}

Springer Nature remains neutral with regard to jurisdictional claims in published maps and institutional affiliations. 